\title{
EFFECT OF NITROGEN FERTILIZATION ON THE INFESTATION BY BEET FLY AND SUCKING INSECTS AND ON PRODUCTIVITY OF SUGARBEET IN EL-MINIA GOVERNORATE
}

Tohamy H. T. ; M. I. El-Khouly and A. M. El-Rawy

Plant Protection Res. Inst., Agricultural Res. Center, Dokki, Giza, Egypt

\begin{abstract}
The present work was carried out to study the effect of four nitrogen fertilizer levels $(40,6080$ and $100 \mathrm{Kg}$. N./Feedan) on the infestation by beet fly, Pegomya mixta and sucking insects, Aphis gossypii, Bemisia tabaci and Empoasca lybica as well as sugarbeet yield during two successive seasons (2005/2006 and 2006/2007) in Mallawi, El-Minia Governorate. In both seasons, the highest rates of infestation by $P$. mixta larvae as well as nymphs and adults of $A$. gossypii, $B$. tabaci and E. lybica were obtained from fertilization with $100 \mathrm{Kg}$. N./Fed., whereas, the lowest infestation rates were recorded on sugarbeet plants fertilized by $40 \mathrm{Kg}$. N./Fed. The maximum root and sugar yields were obtained from sugarbeet plants received $80 \mathrm{Kg}$. N./Fed. The minimum root and sugar yields were produced from fertilization by $40 \mathrm{Kg}$. N./Fed. Fertilizer application at $80 \mathrm{Kg}$. N./Fed. could be useful in reducing the yield losses due to these insects and increase the root and sugar yields.
\end{abstract}

\section{INTRODUCTION}

In Egypt, sugarbeet, Beta vulgaris L. is considered the second important sugar crop after sugarcane. The list of pests attacking sugarbeet plants is long and includes a group of insect pests cause serious problems for growers and cause yield reductions (Bassyouny and Khalafalla, 1996). The sugarbeet fly, Pegomya mixta (Vill.) and sucking insects cause economic losses in sugar yield (Guirguis, 1985 and Bassyouny, 1987). The most serious sucking insects attack this plant are cotton aphid, Aphis gossypii (Glover), whitefly, Bemisia tabaci (Genn.) and cotton leafhopper, Empoasca lybica (de Berg) (Aly et al., 1993; Mousa, 2005 and Shalaby \& Hendawy, 2007).

Nitrogen proved to be one of the greatest influences on root growth and quality as well as sucrose production of sugarbeet (Besheit et al., 1995 and Maareg et al., 2005). There are major constrains for sugarbeet production such as insect infestation and nitrogen. So, the present investigation was conducted to study the effect of nitrogen fertilizer levels on the infestation rate of the four previous insects and the possibility of using the effective rates of nitrogen fertilizer for reducing yield losses due to these insect pests.

\section{MATERIALS AND METHODS}

The present study was carried out at the farm of the Agric. Res. Station, Mallawi District, El-Minia Governorate, during two seasons (2005/2006 and 2006/2007).

An area of about one feddan was divided into 4 equal plots cultivated with Oscar poly sugarbeet variety on $15^{\text {th }}$ November of both seasons. The 
treatments of nitrogen fertilizer were $40,60,80$ and $100 \mathrm{Kg}$. N./Fed. assigned randomaly within each plot represented a randomized complete blocks design. Nitrogen was added, in the form of ammonium nitrate $(33.5 \% \mathrm{~N})$, at two equal doses before the $1^{\text {st }}$ and $2^{\text {nd }}$ irrigation. The other normal cultural practices were applied as recommended with no chemical control.

To determine the infestation and numbers of $P$. mixta larvae and nymphs and adults of $A$. gossypii, B. tabaci and E. lybica, weekly samples of 100 leaves, treatment ( 25 from each plot) were randomaly collected starting from $4^{\text {th }}$ January to $25^{\text {th }}$ May.

At harvest, 25 sugarbeet roots were also randomaly taken from the four middle ridges of each plot. The roots were directly pulled, cleaned and weighed. Sucrose percentages were estimated according to the procedure of Le Docte (1927) in Delta Sugar Company, Kafr El-Sheikh Governorate.

Sugar yield in tons/Fed. = Yield of roots in tones $/$ Fed. Xadjusted sucrose percentage

Statistical analysis was done to show any significant differences among means of the treatments according to Duncan's (1955) method through SAS-Computer program.

\section{RESULTS AND DISCUSSION}

\section{Effect of insect infestation:}

Results in Tables 1 and 3 showed that, the effect percentages of infested leaves as well as number of alive $P$. mixta larvae increased with increasing the nitrogen dose in both seasons. The lowest infestation (3.7$5.4 \%$ ) and larval population (5.2-7.3/100 leaves) were found with the lowest dose of nitrogen ( $40 \mathrm{Kg} . \mathrm{N} . /$ Fed.), increased gradually to reach a maximum of $12.8-16.1 \%$ and $16.1-20.6$ larvae/100 leaves with the highest dose of 100 Kg.N./Fed. The peak of $P$. mixta infestation was found in March of both season expressed as 15.5-31.8 and 8.4-28.5\% infested leaves and as 19.040.5 and 12.3-34.5 larvae/100 leaves in the two seasons, respectively. These results are in agreement with findings of Aly (1988), Zarif and Hagazi (1990) and Soloma (2001), the increase in nitrogen fertilizer caused increase in the infestation with this pest. Also, Maareg et al. (2005) and Mousa (2005) reported that, a positive relation was found between nitrogen levels and number of live $P$. mixta larvae on sugarbeet.

A similar trend was found with A. gossypii, B. tabaci and E. lybica infestation. Regardless of season, the number of these insects increased with increasing the nitrogen dose. While the numbers ranged 6.4-8.8, 5.2-6.1 and 11.4-12.4/100 leaves at $40 \mathrm{Kg} . \mathrm{N} . / \mathrm{Fed}$., they reached a maximum of 16.017.4, 12.1-13.6 and 21.3-23.1 insects/100 leaves with Kg.N./Fed. for the three sucking insects, respectively, Table (2). Also, the peak of population of these insects was noticed in March. In this respect, Mousa (2005) showed that, the numbers of these insects increased also by the increase in the nitrogenous fertilization. Iskandar (1982) found the maximum occurrence of A. gossypii from March to May on sugerbeet plants. Aly et al. (1993) recorded that, the highest infestation by aphids and E. lybica was recorded in October and November plantations. This author added also that, the serious damage by $B$. tabaci was found at mid-August. 
J. Agric. Sci. Mansoura Univ., 33 (1), January, 2008

1-2 
Tohamy H. T.et al.

\section{Effect on yield:}

Data illustrated in Table (3) pointed to that, the root and sugar yield increased with raising the nitrogen dose to 80 units. The root yield was 17.4 tons/Fed. with the least dose (40/Fed.), increased to 23.8 and 29.4 tons/Fed. with 60 and $80 \mathrm{Kg}$./Fed., respectively.

A similar trend was detected in the sugar yield, 1.9 tons/Fed. with 40 $\mathrm{Kg} \mathrm{N}$./Fed. increase to 2.8 tons/Fed. with $80 \mathrm{Kg} \mathrm{N}$./Fed. Adding more than 80 $\mathrm{Kg}$ reduced the yield to 21.9 tons roots and 2.3 tons sugar.

In this respect, Lange (1972) found that, the increase in nitrogen fertilization caused increase in leaf area but decreased the sugar content in sugarbeet plants. Besheit et al. (1995) showed that, the maximum root and sugar yield was detected with $69 \mathrm{Kg} \mathrm{N} . / \mathrm{Fed}$. On the hand, Ibrahim (1998) reported that, more nitrogen than 50 or $60 \mathrm{Kg} \mathrm{N}$./Fed. decreased source \%, Osman (2005) pointed to that, excessive nitrogen than $80 \mathrm{Kg} / \mathrm{Fed}$. deceased root and sugar yield.

A short glance to the data in Table (3) reveals that, raising the fertilizer dose increased the total insect population and in the same time increased root and sugar yield. These results cleared that, the yield (roots and sugar) is more attributed with the fertilizer than insect population.

Finally, it could mention that, fertilizing sugarbeet plants with nitrogen at the rate of $80 \mathrm{Kg} \mathrm{N}$./Fed. is a succefful cultural practice to increase root and sugar yield.

Table (3): Relationship between nitrogen fertilization and the infestation by four insects and yield (two seasons combined data).

\begin{tabular}{|c|c|c|c|c|c|c|c|}
\hline \multirow{2}{*}{$\begin{array}{l}\text { (Kg.N./ } \\
\text { Fed.) }\end{array}$} & \multicolumn{5}{|c|}{ Insets $/ 100$ leaves } & \multicolumn{2}{|c|}{ Yield (ton/Fed.) } \\
\hline & P. mixta & A. gossypi & B. tabaci & E. lybica & Total & Root & Sugar \\
\hline 40 & $6.3^{c}$ & $7.6^{\mathrm{c}}$ & $5.7^{c}$ & $11.9^{c}$ & 31.5 & $17.4^{\mathrm{c}}$ & $1.9^{c}$ \\
\hline 60 & $8.5^{\mathrm{c}}$ & $10.3^{c}$ & $7.6^{c}$ & $15.6^{b}$ & 42.0 & $23.8^{b}$ & $2.4^{\mathrm{b}}$ \\
\hline 80 & $11.5^{\mathrm{b}}$ & $13.3^{b}$ & $10.0^{b}$ & $19.3^{a}$ & 54.1 & $29.4^{a}$ & $2.8^{a}$ \\
\hline 100 & $18.4^{a}$ & $16.7^{a}$ & $12.9^{a}$ & $22.2^{a}$ & 70.2 & $21.9^{b}$ & $2.3^{\mathrm{b}}$ \\
\hline
\end{tabular}

Means followed by same letter in the row of each seasons are significantly no different at $\mathbf{P}=\mathbf{0 . 0 5}$.

\section{REFERENCES}

Aly, F. A. (1988): Effect of nitrogenous and potas fertilization rates on sugarbeet infestation with main insects. J. Agric. Sci. Mansoura Univ., $13(1): 357-361$.

Aly, F. A.; M. A. Samy; F. F. El-Adl and S. M. Ibrahium (1993): Effect of planting dates on the infestation ratio of the main insects in sugarbeet field. J. Agric. Sci. Mansoura Univ., 18 (6): 1805-1812.

Bassyouny, A. M. (1987): Studies on the insects of sugarbeet in Kafr ElSheikh Governorate. Ph.D. Thesis, Fac. Agric. Kafr El-Sheikh, Tanta Univ., $152 \mathrm{Pp}$.

Bassyouny, A. M. and E. M. Khalafalla (1996): Seasonal fluctuations of certain insect pests on three sugarbeet varieties and their chemical control. Alex. Sci. Exch., 17 (4): 381-393. 
Besheit, S. Y.; B. B. Mekka and M. A. El-Sayed (1995): Yield and technological characters of sugarbeet as affected by rates and time of nitrogen application. J. Agric. Sci., 20 (1): 61-69.

Duncan, D.B.(1955):Multiple range and multiple (F) tests. Biometrics,11:1-42.

Guirguis, S. Z. (1985): Studies on certain insects attacking sugarbeet in Western Desert, Egypt.Ph.D.Thesis,Fac.Agric. Monufiya Univ., 171 Pp.

Ibrahim, M. F. M. (1998): The effect of some fertilization elements on the yield and quality of some sugarbeet. Ph.D. Thesis, Fac. Agric., Moshtohor Zagazig Univ.

Iskander, A. K. (1982): Studies on certain sugarbeet insects. M.Sc. Thesis, Fac. Agric., Alex. Univ., 144 Pp.

Le Docte, A. (1927): Commercial determination of sugar in beet root using the socks. Sugar J., $29: 488-492$.

Maareg, M. F.; S. F. Tawfik and A. A. Aboel-Ftooh (2005): Effect of preceding crops and nitrogen fertilization on productivity of sugarbeet and some economic insect pests infestation in newly reclaimed soil at Wets Nubaryia region. Egypt, J. Agric. Res., 83 (2): 741-757.

Mousa, E. A. M. (2005): Studies on sugarbeet main insects and their safety control methods. Ph.D. Thesis, Fac. Agric. Mansoura Univ., 294 Pp.

Osman, A. M. H. (2005): Influence of nitrogen and potassium fertilization on yield and quality of two sugarbeet varieties. Egypt, J. Agric. Res., 83 (3): 1237-1254.

Shalaby, G. M. and A. S. Hendawy (2007): Leafhoppers and their associated parasitoides in sugarbeet fields. Egypt, J. Agric. Res., 85 (3): 967-975.

Solouma, A. G. (2001): Effect of preceding summer crops and nitrogen fertilization on the rate of infestation by tortoise beetle, Cassida vittata (Vill.) and beet fly, Pegomyia mixta (Vill.) on sugarbeet in the new reclaimed areas. Annals of Agric. Sci. Moshtohor, 39 (4): 2469-2474.

Zarif, G. and E. M. Hagazi (1990): Effect of nitrogen fertilization and sugarbeet cultivars on population of beet fly, Pegomyia mixta (Vill.) (Diptera : Anthomyidae). Com. Sci. and Dev. Res., 29:1-10.

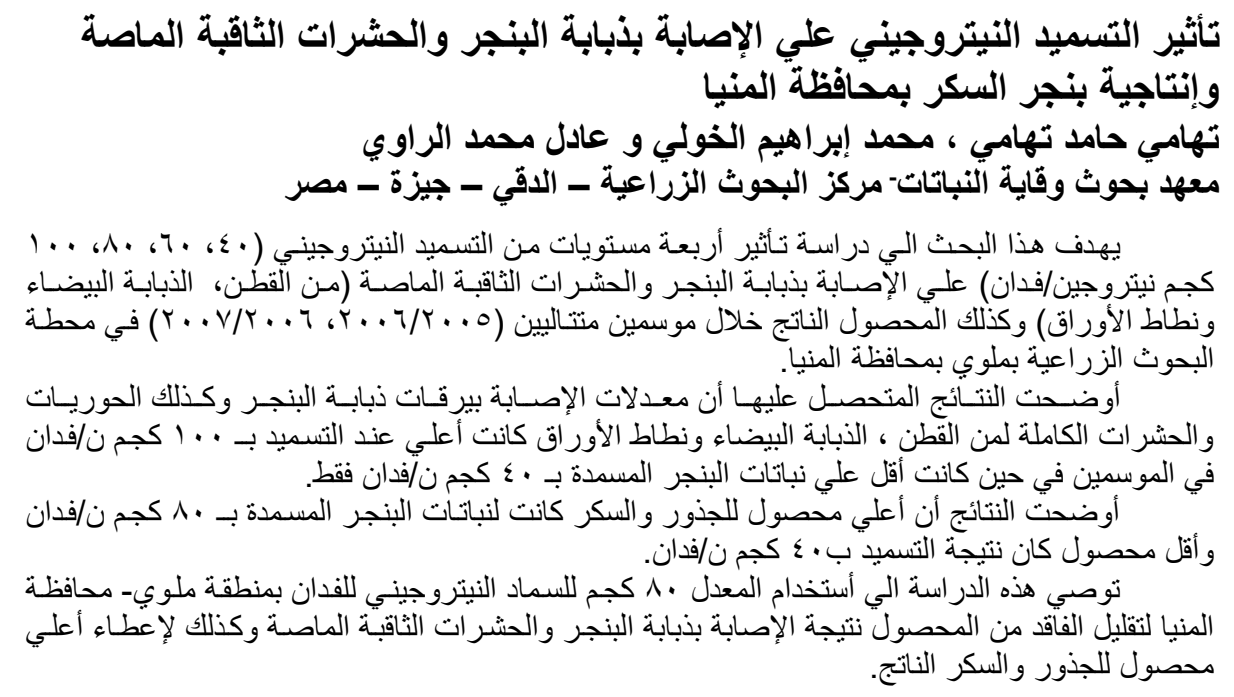



Table (1): Monthly means of the percentage of the infested leaves and number of alive $P$. mixta larvae in relation to different levels of nitrogen fertilization in sugarbeet fields during 2005/2006 and 2006/2007 seasons.

\begin{tabular}{|c|c|c|c|c|c|c|c|c|c|c|c|c|c|c|c|c|}
\hline \multirow{3}{*}{ Month } & \multicolumn{8}{|c|}{$\%$ Infested leaves } & \multicolumn{8}{|c|}{ Alive larvae/100 leaves } \\
\hline & \multicolumn{4}{|c|}{$2005 / 2006$} & \multicolumn{4}{|c|}{$2006 / 2007$} & \multicolumn{4}{|c|}{$2005 / 2006$} & \multicolumn{4}{|c|}{$2006 / 2007$} \\
\hline & $\mathbf{N}_{1}$ & $\mathbf{N}_{2}$ & $\mathrm{~N}_{3}$ & $\mathbf{N}_{4}$ & $\mathbf{N}_{1}$ & $\mathbf{N}_{2}$ & $\mathrm{~N}_{3}$ & $\mathbf{N}_{4}$ & $\mathbf{N}_{1}$ & $\mathbf{N}_{2}$ & $\mathbf{N}_{3}$ & $\mathbf{N}_{4}$ & $\mathbf{N}_{1}$ & $\mathbf{N}_{2}$ & $\mathbf{N}_{3}$ & $\mathbf{N}_{4}$ \\
\hline Jan. & 1.3 & 2.4 & 4.9 & 5.6 & 1.5 & 2.7 & 3.3 & 5.5 & 2.0 & 3.3 & 5.8 & 7.8 & 1.5 & 3.0 & 4.5 & 6.3 \\
\hline Feb. & 4.7 & 8.5 & 11.3 & 15.8 & 3.0 & 6.1 & 8.3 & 11.8 & 7.8 & 10.8 & 13.8 & 17.8 & 5.0 & 7.3 & 11.3 & 14.3 \\
\hline March & 15.5 & 18.3 & 22.3 & 31.8 & 8.4 & 13.2 & 17.0 & 28.5 & 19.0 & 21.3 & 26.5 & 40.5 & 12.3 & 16.3 & 20.8 & 34.5 \\
\hline April & 3.7 & 6.9 & 10.7 & 19.8 & 3.5 & 4.8 & 7.3 & 12.5 & 5.0 & 9.0 & 13.0 & 27.3 & 4.3 & 5.3 & 8.5 & 17.8 \\
\hline May & 1.8 & 2.2 & 3.5 & 7.5 & 2.3 & 3.9 & 4.5 & 5.7 & 2.5 & 4.0 & 5.0 & 9.5 & 3.0 & 4.5 & 5.8 & 7.5 \\
\hline Total & 27.0 & 38.3 & 52.7 & 80.5 & 18.7 & 30.7 & 40.4 & 64 & 36.3 & 48.4 & 64.1 & 102.9 & 26.1 & 36.4 & 50.9 & 80.4 \\
\hline Mean & $5.4^{\mathrm{c}}$ & $7.7^{\mathrm{c}}$ & $10.5^{b}$ & $16.1^{\mathrm{a}}$ & $3.7^{\mathrm{c}}$ & $6.1^{\mathrm{b}}$ & $8.1^{\mathrm{b}}$ & $12.8^{\mathrm{a}}$ & $7.3^{c}$ & $9.7^{c}$ & $12.8^{\mathrm{b}}$ & $20.6^{a}$ & $5.2^{c}$ & $7.3^{c}$ & $10.2^{b}$ & $16.1^{\mathrm{a}}$ \\
\hline
\end{tabular}

$\mathrm{N}_{1}=40 \mathrm{Kg} ., \mathrm{N}_{2}=60 \mathrm{Kg} ., \mathrm{N}_{3}=80 \mathrm{Kg}$. and $\mathrm{N}_{4}=100 \mathrm{Kg}$. N. $/$ Fed.

Means followed by the same letter in the row of each season are significantly not different at $P=0.05$.

Table (2): Monthly numbers of A. gossypii, B. tabaci and E. lybica individuals in relation to different levels of nitrogen fertilization in sugarbeet fields during 2005/2006 and 2006/2007 seasons.

\begin{tabular}{|c|c|c|c|c|c|c|c|c|c|c|c|c|c|c|c|c|c|c|c|c|c|c|c|c|}
\hline \multirow{3}{*}{ Month } & \multicolumn{8}{|c|}{ A. gossypii } & \multicolumn{8}{|c|}{ B. tabaci } & \multicolumn{8}{|c|}{ E. lybica } \\
\hline & \multicolumn{4}{|c|}{$2005 / 2006$} & \multicolumn{4}{|c|}{ 2006/2007 } & \multicolumn{4}{|c|}{$2005 / 2006$} & \multicolumn{4}{|c|}{$2006 / 2007$} & \multicolumn{4}{|c|}{ 2005/2006 } & \multicolumn{4}{|c|}{ 2006/2007 } \\
\hline & $\mathbf{N}_{1}$ & $\mathbf{N}_{2}$ & $\mathbf{N}_{3}$ & $\mathbf{N}_{4}$ & $\mathbf{N}_{1}$ & $\mathrm{~N}_{2}$ & $\mathrm{~N}_{3}$ & $\mathbf{N}_{4}$ & $\mathbf{N}_{1}$ & $\mathbf{N}_{2}$ & $\mathbf{N}_{3}$ & $\mathbf{N}_{4}$ & $\mathbf{N}_{1}$ & $\mathbf{N}_{2}$ & $\mathbf{N}_{3}$ & $\mathbf{N}_{4}$ & $\mathbf{N}_{1}$ & $\mathrm{~N}_{2}$ & \begin{tabular}{|l|}
$N_{3}$ \\
\end{tabular} & $\mathbf{N}_{4}$ & $\mathbf{N}_{1}$ & $\mathbf{N}_{2}$ & $\mathrm{~N}_{3}$ & $\mathbf{N}_{4}$ \\
\hline Jan. & 4.5 & 6.3 & 8.5 & 11.3 & 4.5 & 5.3 & 7.0 & 7.5 & 0.5 & 1.3 & 2.5 & 3.3 & 0.5 & 1.3 & 2.0 & 2.8 & 7.3 & 9.3 & 9.3 & 9.8 & 4.5 & 6.5 & 8.0 & 8.8 \\
\hline Feb. & 5.3 & 6.5 & 10.8 & 12.8 & 7.3 & 10.0 & 12.0 & 16.0 & 4.0 & 5.8 & 7.3 & 9.0 & 4.8 & 8.8 & 12 & 11.5 & 15.0 & 21.5 & 25.8 & 24.3 & 10.3 & 12.5 & 15.5 & 18.5 \\
\hline March & 11.0 & 15.0 & 20.4 & 28.8 & 15.8 & 19.0 & 23.6 & 29.2 & 7.3 & 10.0 & 11.8 & 16.8 & 11 & 13.6 & 16.4 & 20.8 & 18.0 & 26.2 & 33.8 & 40 & 19.2 & 23.0 & 33.8 & 39.2 \\
\hline
\end{tabular}


Tohamy H. T.et al.

\begin{tabular}{|c|c|c|c|c|c|c|c|c|c|c|c|c|c|c|c|c|c|c|c|c|c|c|c|c|}
\hline April & 7.0 & 10.5 & 12.0 & 16.5 & 12.8 & 16.8 & 21.5 & 22.0 & 13.2 & 16.6 & 19.4 & 27.6 & 12 & 14.5 & 22.8 & 28.0 & 16.8 & 25.0 & 28.3 & 34 & 18.3 & 20.5 & 24.5 & 29.0 \\
\hline May & 4.0 & 6.0 & 7.3 & 10.8 & 3.5 & 7.3 & 9.5 & 12.5 & 0.8 & 2.3 & 3.0 & 3.8 & 2.0 & 2.0 & 2.5 & 4.8 & 4.8 & 4.8 & 6.0 & 7.3 & 4.5 & 6.5 & 7.8 & 11.0 \\
\hline Total & 31.8 & 44.3 & 59 & 80.2 & 43.9 & 58.4 & 73.6 & 78.2 & 25.8 & 36 & 44 & 60.5 & 30.3 & 40.2 & 55.7 & 67.9 & 61.9 & 86.8 & 103.2 & 115.4 & 56.8 & 69.0 & 89.6 & 106.5 \\
\hline Mean & $6.4^{\mathrm{c}}$ & $8.9^{c}$ & $11.8^{b}$ & $16.0^{a}$ & $8.8^{\mathrm{c}}$ & $11.7^{b}$ & $14.7^{\mathrm{a}}$ & \begin{tabular}{|l|l}
$17.4^{\mathrm{a}}$ \\
\end{tabular} & $5.2^{\mathrm{c}}$ & $7.2^{c}$ & $8.8^{b}$ & $12.1^{\mathrm{a}}$ & $6.1^{\mathrm{b}}$ & $8.0^{b}$ & $11.1^{\mathrm{a}}$ & $13.6^{\mathrm{a}}$ & $12.4^{c}$ & $17.4^{b}$ & $20.6^{\mathrm{a}}$ & $23.1^{\mathrm{a}}$ & $11.4^{b}$ & $13.8^{b}$ & $17.9^{\circ}$ & $21.3^{\mathrm{a}}$ \\
\hline
\end{tabular}

$N_{1}=40 \mathrm{Kg}, \mathrm{N}_{2}=60 \mathrm{Kg}, \mathrm{N}_{3}=80 \mathrm{Kg}$. and $\mathrm{N}_{4}=100 \mathrm{Kg}$. N./Fed.

Means followed by the same letter in the row of each season are significantly not different at $P=0.05$. 